\title{
The Uptake, Accumulation, and Toxic Effects of Cadmium in Barnyardgrass (Echinochloa crus-galli)
}

\author{
Qiong Peng, Wei Chen, Lamei Wu, Lianyang Bai* \\ Biotechnology Research Center, Hunan Academy of Agricultural Sciences, \\ Changsha, 410125, Hunan, the People's Republic of China \\ Collaborative Innovation Center for Field Weeds Control, \\ Loudi, 417000, Hunan, the People's Republic of China
}

Received: 19 August 2016

Accepted: 11 October 2016

\begin{abstract}
Cadmium $(\mathrm{Cd})$ is regarded as one of the most toxic environmental pollutants. A better understanding of the growth response, uptake, and translocation of Cd in barnyard grass (Echinochloa crus-galli) would be helpful for evaluating the role of this grass species as a potential candidate to be used for phytoremediation. The studied plants were grown in treated soils with increasing doses of $\mathrm{Cd}\left(0,0.3,0.6,0.9\right.$, and $\left.1.5 \mathrm{mg} \cdot \mathrm{kg}^{-1}\right)$. The results showed that $\mathrm{Cd}$ contents in plant tissues were found to increase with increasing doses of $\mathrm{Cd}$. The pattern of $\mathrm{Cd}$ accumulation in different parts of the plant were found as: root $>$ aboveground part $>$ seed. Translocation factor (TF) values were found to be less than 1, and translocation from root to aboveground part was found to be higher as compared to that of aboveground part to seed. There was no significant difference on the aboveground part fresh weight (FW) and tiller number per plant under different concentrations of $\mathrm{Cd}$ stress. The root FW and the lengths of roots and shoots were significantly decreased in response to $\mathrm{Cd}$ treatments at low concentrations. However, the $1.5 \mathrm{mg} \cdot \mathrm{kg}^{-1} \mathrm{Cd}$ application didn't affect significant changes on the root and shoot length than that of the control. A high concentration of cadmium supply could promote chlorophyll content. SOD showed a similar trend to POD in Cd-exposed plants, with an increase at lower concentrations and a decrease at higher concentrations.
\end{abstract}

Keywords: cadmium, uptake, accumulation, physiological changes, barnyard grass

\section{Introduction}

Cadmium $(\mathrm{Cd})$ is one of the most toxic trace elements (No. 7 among the top 20 toxins), and is well known to be harmful to plants by inhibiting several plant physiological

*e-mail: bailianyang2005@aliyun.com processes such as oxidative reactions and nitrogen metabolism [1-2]. Cd-polluted soil in agricultural land, especially paddy fields, usually caused by irrigation water containing $\mathrm{Cd}$ running out from industrial and urban activity, transportation, and agricultural practices, has become a serious problem since $\mathrm{Cd}$ is also toxic to humans [3].

Root uptake and root-to-shoot translocation of $\mathrm{Cd}$ are two key physiological processes in $\mathrm{Cd}$ accumulation 
of plants [4]. It has been shown that plants are highly sensitive to Cd stress [5]. Cadmium stress in plants leads to a series of stress symptoms, including wilting, chlorosis, cell death, necrotic lesions, and growth reduction [6]. Moreover, Cd stress may disturb mineral nutrition [7] and carbohydrate metabolism [8], and may strongly reduce biomass production (Liu et al., 2010). The photosynthetic apparatus is particularly susceptible to $\mathrm{Cd}$ and a reduction of photosynthesis is a common response in plants exposed to $\mathrm{Cd}[9]$. As $\mathrm{Cd}$ is unable to participate directly in biological redox reactions, it induces oxidative stress via different indirect mechanisms [10-11]. However, the toxic effects of $\mathrm{Cd}$ on plants depend on stress intensity and plant species [12-13]. Therefore, researching a plant's abilities for absorption, transfer, and accumulation of $\mathrm{Cd}$ and responses to toxicity induced by $\mathrm{Cd}$ is crucial for crop production, even for the protection of human health.

Barnyard grass (Echinochloa crus-galli) is a major weed of different field crops, especially rice. E. crus-galli can produce large number of seeds and grow better than crop plants in adverse environments, e.g., in nutrientdeficient and/or contaminated soil. It may cause a $21-79 \%$ yield loss in rice, depending upon the cropping system and management [14-15]. Interestingly, there is increased evidence showing that $E$. crus-galli may play an important role in improving heavy metal-contaminated soil $[3,17-$ 18]. Therefore, a better understanding of the toxicity of $\mathrm{Cd}$ and the ability of E. crus-galli to remove Cd is important for evaluating the potential ability of this weed species for phytoremediation.

In the present study, we examined the effect of $\mathrm{Cd}$ on toxicity in barnyard grass. Our experimental aims were to determine: 1) the effect of different concentrations on $\mathrm{Cd}$ uptake and distribution in different parts and 2) plant physiological responses to $\mathrm{Cd}$ at different concentrations.

\section{Material and Methods}

The experiments and analysis were respectively conducted at the experimental farm of Hunan Academy of Agricultural Sciences, China. Echinochloa crus-galli seeds from the city of Yuanjiang in Hunan Province were kept in $2 \% \mathrm{v} / \mathrm{v} \mathrm{KNO}_{3}$ solution overnight, then washed and grown on moistened filter paper for two days. The germinated seeds were transferred to cylindrical plastic pots of 28 $\mathrm{cm}$ diameter and $17 \mathrm{~cm}$ depth filled with $3.0 \mathrm{~kg}$ of sieved dry paddy soil (the contents of soil organic matter, total nitrogen, total phosphorus, alkaline hydrolytic nitrogen, effective phosphorus, and total cadmium were $3.72 \%$, $1.20 \mathrm{~g} \cdot \mathrm{kg}^{-1}, 1.02 \mathrm{~g} \cdot \mathrm{kg}^{-1}, 164.35 \mathrm{mg} \cdot \mathrm{kg}^{-1}, 54.28 \mathrm{mg} \cdot \mathrm{kg}^{-1}$, and $0.30 \mathrm{mg} \cdot \mathrm{kg}^{-1}$, respectively, and soil $\mathrm{pH}$ was 5.7 ). Soil was spiked by adding a distilled water solution of $\mathrm{Cd}\left(\mathrm{NO}_{3}\right)_{2}$ and mixed thoroughly. All pots were properly cared for as required according to conventional field management measures.

Treatments were set up with five levels of $\mathrm{Cd}$ contamination, i.e., 0-control, 0.3, 0.6, 0.9, and $1.5 \mathrm{mg}$ $\mathrm{Cd} / \mathrm{kg}$ soil dry weight. Four pots of barnyard grass plants were considered one treatment. The entire experiment was performed according to a complete randomized design (CRD). Each experiment was replicated three times.

\section{Determining Cadmium in Plants}

Harvested plants were thoroughly washed in distilled water and roots, seeds, and aboveground parts were separated, then oven dried at $80^{\circ} \mathrm{C}$. Dried plant material $(500 \mathrm{mg})$ was powdered and digested in an $\mathrm{HNO}_{3} / \mathrm{HClO}_{4}$ $(9: 1, \mathrm{v} / \mathrm{v})$ mixture using the wet digestion method. $\mathrm{Cd}$ concentration was routinely verified by inductively coupled plasma mass spectroscopy (ICP-MS, iCAP Qc, Thermo Fisher Scientific, USA). The cadmium translocation ability of E. crus-galli plants was assessed using the translocation factor (TF) calculated as follows.

$\mathrm{TF}=\mathrm{Cd}$ concentration in shoot $/ \mathrm{Cd}$ concentration in root

\section{Determination of Physiological Parameters}

\section{Concentration of Photosynthetic Pigments}

At tillering stage, the photosynthetic pigment concentrations were determined in the second leaves from the top by the extraction of leaf samples in $80 \%(\mathrm{v} / \mathrm{v})$ acetone. The absorbance of the resulting extracts were measured at $663 \mathrm{~nm}, 646 \mathrm{~nm}$, and $470 \mathrm{~nm}$. The concentrations of chlorophyll a and b and total carotenoids (xanthophylls + carotenes) was determined according to the equations given by Lichtenthaler and Wellburn (1983) [19].

\section{Determination of Plant Growth}

Plant growth was used as one of an important criterion to assess Cd toxicity. At mature stage, the plants were harvested, washed with tap water, rinsed with deionized water, and dried on absorbent towels. The tiller number per plant, the lengths of stems and roots, and the fresh weights of roots and aboveground parts were recorded.

\section{Activities of Antioxidant Enzymes}

At tillering stage, plant material (500 mg, leaves) was homogenized in $100 \mathrm{mM}$ potassium phosphate buffer (pH 7.0) containing $0.1 \mathrm{mM}$ EDTA at $4^{\circ} \mathrm{C}$. Homogenate was filtered through four layers of cheese cloth and centrifuged at $4,000 \times \mathrm{g}$ for $15 \mathrm{~min}$ at $4^{\circ} \mathrm{C}$. Supernatant was used for enzyme activity and protein determinations. SOD activity was measured as the inhibition in the photochemical reduction of nitroblue tetrazolium (NBT) spectrophotometrically at $560 \mathrm{~nm}$ [20]. POD activity was measured following a protocol using guaiacol [21].

\section{Statistical Analysis}

The experimental data reported were averages of three replicates. All statistical analyses were performed with data processing system software SPSS version 18.0 
for Windows. Means and standard deviation were used for data that were analyzed using the least significant difference (LSD) method at the 5\% level.

\section{Results and Discussion}

Cadmium (Cd) is one of the most highly toxic trace pollutants for humans, animals, and plants. There are three transport processes most likely to mediate $\mathrm{Cd}$ accumulation into the shoots and, subsequently, into the seeds: (i) uptake by roots, (ii) xylem-loading-mediated translocation to shoots, and (iii) further translocation to seeds via the phloem [22].

\section{Cadmium Accumulation of Different Plant Parts of E. crus-galli}

In our study, data for Cd accumulation in E. crus-galli tissues indicated that most of the metal was accumulated in roots and a lower fraction was translocated to the aboveground parts, and values decreased in the order as roots $>$ aboveground parts $>$ seeds (Fig. 1). The concentrations of $\mathrm{Cd}$ in different parts of the plants were gradually increased with the increase of $\mathrm{Cd}$ in the soil. Cadmium contents were significantly increased with 0.6 , 0.9 , and $1.5 \mathrm{mg} \cdot \mathrm{kg}^{-1} \mathrm{Cd}$ stresses in roots, indicating that uptake of $\mathrm{Cd}$ in roots is a key process in barnyard grass plant $\mathrm{Cd}$ accumulation. Similar results were reported in various plants [23-24]. Aboveground parts exposed to 0.9 and $1.5 \mathrm{mg} \cdot \mathrm{kg}^{-1} \mathrm{Cd}$ showed a significantly higher $\mathrm{Cd}$ accumulation than that of the control. Plants grown in $\mathrm{Cd}$ spiked soil had a higher Cd concentration in seed than that of the control, and the increases were $30.23 \%, 93.02 \%$, $102.33 \%$, and $162.79 \%$, with $0.3,0.6,0.9$, and $1.5 \mathrm{mg} \cdot \mathrm{kg}^{-1}$ $\mathrm{Cd}$ stresses, respectively. The significant increases of $\mathrm{Cd}$ content were not observed in roots and aboveground parts with $0.3 \mathrm{mg} \cdot \mathrm{kg}^{-1} \mathrm{Cd}$ treatment, indicating that the presence of $\mathrm{Cd}$ at low concentration may not impact the Cd uptake of plants.

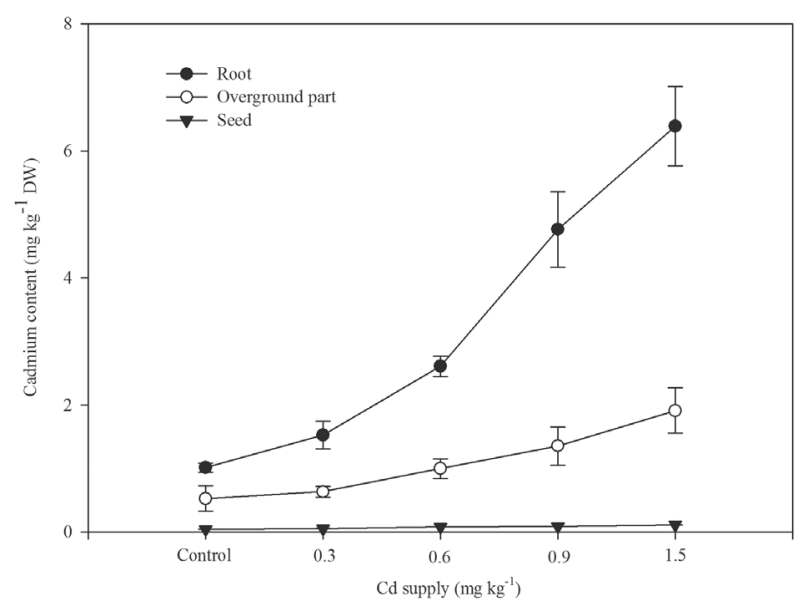

Fig. 1. Cadmium content in different parts of root, aboveground part, and seed with cadmium application.

\section{Cadmium Translocation in Different Plant Parts of E. crus-galli}

$\mathrm{TF}$ is the ratio of metal concentration in the aboveground plant part to that in root, being used to measure the effectiveness of a plant in translocating a metal from the roots to the aboveground plant parts [25]. The higher the $\mathrm{TF}$ value of a plant, the more the plant is suitable for phytoremediation through phytoextraction. The translocation factor (TF) of Cd from root to aboveground part and aboveground part to seed is presented in Table 1. It was clear that increased concentration of Cd significantly decreased the translocation of $\mathrm{Cd}$ from aboveground part to seed. Translocation from aboveground part to seed was found to be lower as compared to that of root to aboveground parts, which revealed that higher accumulation of $\mathrm{Cd}$ in root tissues and promotion of the aboveground part growth of E. crus-galli may be an effective route for soil remediation. All translocation factor values were found to be less than 1 . The TF values of barnyard grass were found to be obviously decreased with the increase of $\mathrm{Cd}$ in the soil, which may be due to limited root-to-shoot transport when internal Cd concentration was high, which was similar to the previously reported results of cadmium accumulation in sunflower (Helianthus annuus L.) plants [26].

\section{Effects of Cadmium Application on Changes in Plant Growth Parameters}

$\mathrm{Cd}$ is one of the most commonly found metals in soil, which limits crop productivity worldwide as this metal tends to accumulate within plant organs and negatively interfere with essential physiological processes [27]. In order to examine the growth parameters of E. crus-galli in different treatments, the roots and aboveground part FW and length as well as tiller number per plant were determined (Table 2). There was no significant difference in the aboveground part FW and tiller number per plant under different concentrations of $\mathrm{Cd}$ stress. Compared with the control, 0.3 and $0.6 \mathrm{mg} \cdot \mathrm{kg}^{-1}$ $\mathrm{Cd}$ stress caused a significant decrease in root $\mathrm{FW}$ by

Table 1. TF of cadmium from root-to-aboveground part and from aboveground part-to-seed of E. crus-galli.

\begin{tabular}{|c|c|c|}
\hline $\begin{array}{c}\text { Treatments } \\
\left(\mathrm{mg} \cdot \mathrm{kg}^{-1}\right)\end{array}$ & $\begin{array}{c}\text { TF } \\
\text { (From root to } \\
\text { aboveground part) }\end{array}$ & $\begin{array}{c}\text { TF } \\
\text { (From aboveground } \\
\text { part to seed) }\end{array}$ \\
\hline 0.3 & $0.445 \pm 0.023 \mathrm{a}$ & $0.088 \pm 0.008 \mathrm{a}$ \\
\hline 0.6 & $0.374 \pm 0.007 \mathrm{~b}$ & $0.083 \pm 0.004 \mathrm{~b}$ \\
\hline 0.9 & $0.252 \pm 0.017 \mathrm{c}$ & $0.064 \pm 0.005 \mathrm{c}$ \\
\hline 1.5 & $0.323 \pm 0.015 \mathrm{~b}$ & $0.059 \pm 0.005 \mathrm{~d}$ \\
\hline
\end{tabular}

Values are mean \pm standard error (SE) of three replications. Different small letters within the same short columns indicate significant differences between treatments according to Duncan's multiple range test at $p<0.05$ level. 
Table 2. Effects of cadmium application on the growth parameters of E. crus-galli.

\begin{tabular}{|c|c|c|c|c|c|}
\hline \multirow{2}{*}{$\begin{array}{c}\text { Treatments } \\
\left(\mathrm{mg} \cdot \mathrm{kg}^{-1}\right)\end{array}$} & Root & Aboveground parts & Root & Aboveground parts & $\begin{array}{c}\text { Till number per } \\
\text { plant }\end{array}$ \\
\cline { 2 - 6 } & $15.36 \pm 0.58 \mathrm{~b}$ & $30.07 \pm 4.69 \mathrm{a}$ & $30.60 \pm 0.94 \mathrm{bc}$ & $122.83 \pm 2.02 \mathrm{~b}$ & $6.00 \pm 0.58 \mathrm{a}$ \\
\hline 0.3 & $17.48 \pm 0.58 \mathrm{~b}$ & $24.97 \pm 2.01 \mathrm{a}$ & $29.17 \pm 1.43 \mathrm{c}$ & $110.40 \pm 3.65 \mathrm{~b}$ & $5.33 \pm 0.33 \mathrm{a}$ \\
\hline 0.6 & $23.97 \pm 0.58 \mathrm{a}$ & $45.84 \pm 1.98 \mathrm{a}$ & $35.67 \pm 2.41 \mathrm{a}$ & $112.80 \pm 1.31 \mathrm{~b}$ & $5.67 \pm 0.89 \mathrm{a}$ \\
\hline 0.9 & $21.72 \pm 0.58 \mathrm{a}$ & $43.56 \pm 5.79 \mathrm{a}$ & $34.93 \pm 1.21 \mathrm{ab}$ & $109.53 \pm 2.28 \mathrm{a}$ & $6.67 \pm 0.65 \mathrm{a}$ \\
\hline 1.5 & $23.54 \pm 4.33 \mathrm{a}$ & $32.01 \pm 3.44 \mathrm{a}$ & $37.53 \pm 0.94 \mathrm{a}$ & $124.33 \pm 0.58 \mathrm{a}$ & $6.00 \pm 0.48 \mathrm{a}$ \\
\hline Control & & &
\end{tabular}

Values are mean \pm standard error (SE) of three replications. Different small letters within the same short columns indicate significant differences between treatments according to Duncan's multiple range test at $p<0.05$ level.

34.75 and $25.74 \%$, respectively. No significant differences in root $\mathrm{FW}$ were observed between $0.9 \mathrm{mg} \mathrm{kg}^{-1}$ and $1.5 \mathrm{mg} \cdot \mathrm{kg}^{-1} \mathrm{Cd}$ stress and the control. The root lengths of the 0.3 and $0.6 \mathrm{mg} \cdot \mathrm{kg}^{-1} \mathrm{Cd}$-treated plants were significantly reduced by 18.47 and $22.28 \%$, than that of control. In addition, shoot lengths were severely decreased by $1.21,11.20$, and $9.28 \%$, respectively, in response to $0.3,0.6$, and $0.9 \mathrm{mg} \cdot \mathrm{kg}^{-1} \mathrm{Cd}$ treatments, which are similar to those obtained by Ullah et al. (2012) [28]. However, the $1.5 \mathrm{mg} \cdot \mathrm{kg}^{-1} \mathrm{Cd}$ application didn't affect significant changes on root and shoot length compared to control. Similarly, in carrot and radish (Raphanus sativus) exposed to increasing $\mathrm{Cd}$ concentrations, there was no significant difference in the development of cotyledons or new leaves [29]. To a certain extent, we speculated that E. crus-galli had tolerant potential to Cd stress regarding growth parameters.

\section{Effects of Cadmium Application on Changes of Leaf Chlorophyll Content}

In green plants' life activity, chlorophyll plays the role of absorbing, transferring, and transforming energy. Chlorophyll content was strongly reduced in tomato (Lycopersicon esculentum) [30] and garden cress [27]. However, the exposure of E. crus-galli to 0.9 and $1.5 \mathrm{mg} \cdot \mathrm{kg}^{-1} \mathrm{Cd}$ significantly increased the concentration of chlorophyll $\mathrm{a}$ and $\mathrm{b}$ in comparison to the control plants (Figs 2a-b). The concentration of $\mathrm{Chl}$ a was similar to the control plants and in plants exposed to $0.6 \mathrm{mg} \cdot \mathrm{kg}^{-1} \mathrm{Cd}$. The decline of the $\mathrm{Chl} \mathrm{b}$ concentration in the $0.6 \mathrm{mg} \cdot \mathrm{kg}^{-1} \mathrm{Cd}$ exposed plants reached $12.70 \%$ more than the control. The ratio of $\mathrm{Chl} \mathrm{a} / \mathrm{b}$ and the concentration of carotenoids was increased significantly in $\mathrm{Cd}$-exposed plants compared
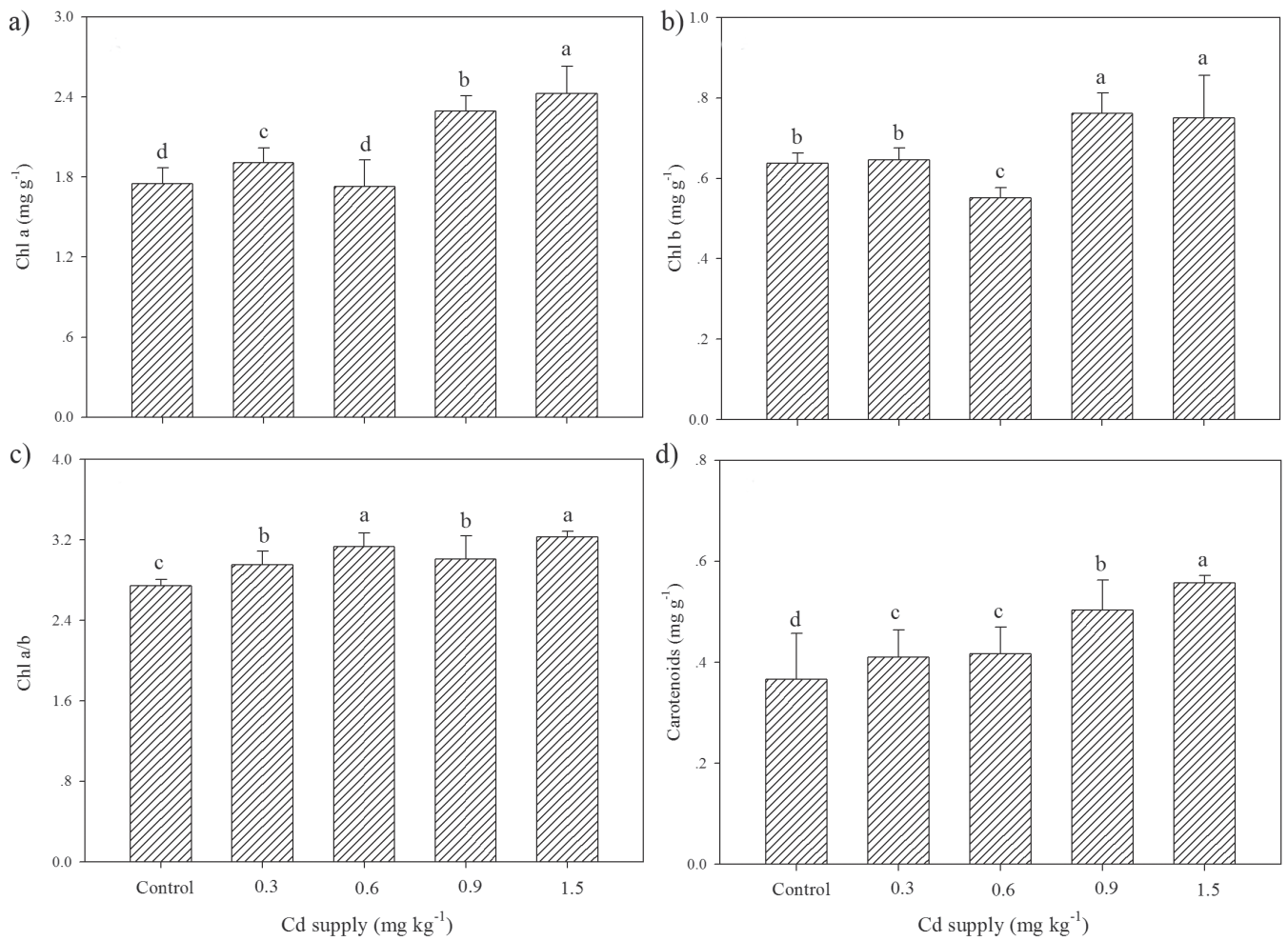

Fig. 2. Changes of leaf chlorophyll a), chlorophyll b), the ratio of chlorophyll a/b, and carotenoids with cadmium application. 
to the control plants (Figs 2c-d), indicating that a high concentration of cadmium supply could promote the chlorophyll contents. Meanwhile, carotenoid increases in E. crus-galli plants exposed to different $\mathrm{Cd}$ concentrations may reflect an attempt to protect chlorophyll and/or the photosynthetic apparatus from the photooxidative destruction caused by Cd toxicity.

\section{Effects of Cadmium Application on the Changes of Leaf Antioxidant Enzyme Activities}

In tolerant plant species, POD activity was found to be higher, enabling plants to protect themselves against oxidative stress [31]. In the present study, compared to the control, the addition of 0.3 or $0.6 \mathrm{mg} \cdot \mathrm{kg}^{-1} \mathrm{Cd}$ caused an increase in the level of POD by $84.74 \%$ and $44.11 \%$, respectively. On the contrary, the POD levels decreased by $50.66 \%$ and $54.10 \%$ under 0.9 and $1.5 \mathrm{mg} \cdot \mathrm{kg}^{-1} \mathrm{Cd}$ stress, respectively (Fig. 3).

Activities of SOD and POD in Chinese cabbage roots were lower in the $\mathrm{Cd}$ treatment than the control [32]. In our study, SOD showed a similar trend to POD in Cd-

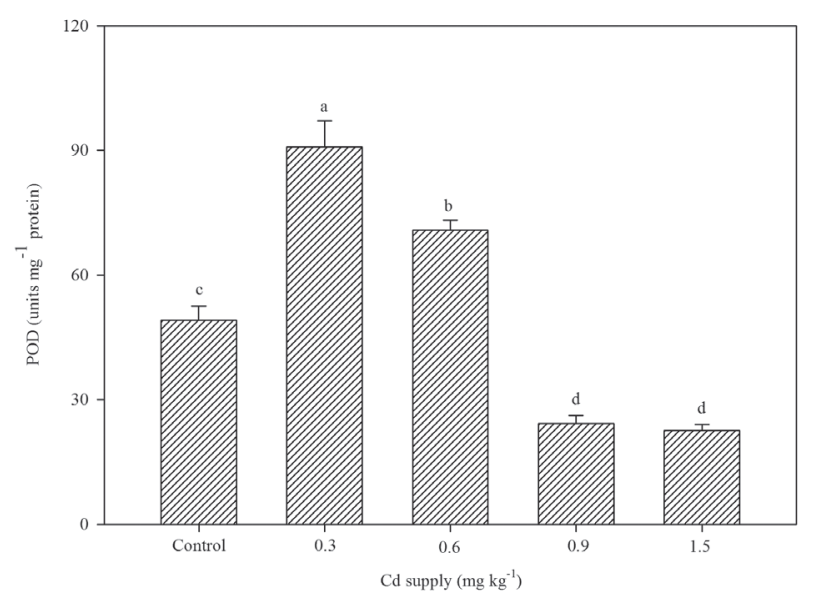

Fig. 3. Leaf POD activities with cadmium application.

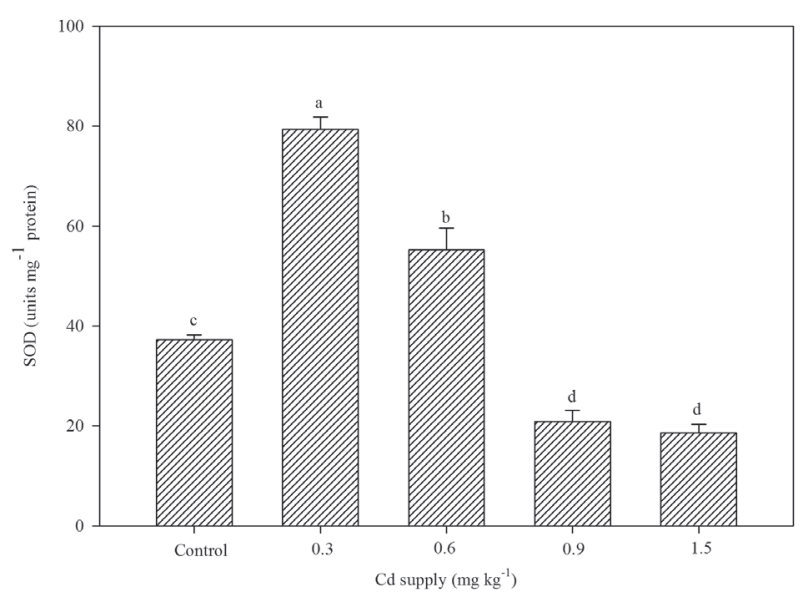

Fig. 4. Leaf SOD activities with cadmium application. exposed plants, with increases at lower concentrations and decreases at higher concentrations (Fig. 4). Treatments with 0.3 or $0.6 \mathrm{mg} \cdot \mathrm{kg}^{-1} \mathrm{Cd}$ resulted in $113.13 \%$ and $48.17 \%$ increases in SOD compared with that of the control. SOD activities were distinctly lower than that of the control by $43.96 \%$ and $50.11 \%$, respectively. Antioxidant enzymes generally showed stimulation at lower cadmiumcontaminated concentrations and decreased at higher cadmium-contaminated concentrations. Increases in SOD activity may be attributed to the increased production of active oxygen species or increased expression of genes encoding SOD [33]. A reduction in SOD activity at higher $\mathrm{Cd}$ concentrations may be attributed to an inactivation of enzymes by $\mathrm{H}_{2} \mathrm{O}_{2}$, which is produced in different cellular compartments and also from a number of non-enzymatic and enzymatic processes in cells.

\section{Conclusions}

In conclusion, our results demonstrated that the uptake and translocation of $\mathrm{Cd}$ in barnyard grass (Echinochloa crus-galli) and the growth response at different $\mathrm{Cd}$ treatments is the physiological basis for evaluating the role of this grass species as a potential candidate to be used for phytoremediation.

\section{Acknowledgements}

This work was financially supported by Major Special Projects of the Hunan Provincial Government, Hunan Provincial Key Laboratory for Biology and Control of Weeds (2015TP1016), and the Scientific-Innovative Team of the Hunan Academy of Agricultural Sciences (2014TD01).

\section{References}

1. GILL S.S., TUTEJA N. Cadmium stress tolerance in crop plants: Probing the role of sulfur. Plant Signal Behav, 6, 2, 215, 2011.

2. PODAZZA G., ARIAS M., PRADO F.E. Cadmium accumulation and strategies to avoid its toxicity in roots of the citrus rootstock Citrumelo. J Hazard Mater, 215-216, 83, 2012.

3. ABE T., FUKAMI M., OGASAWARA M. Cadmium accumulation in the shoots and roots of 93 weed species. Soil Sci Plant Nutr, 54, 566, 2008.

4. URAGUCHI S., MORI S., KURAMATA M., KAWASAKI A., ARAO T., ISHIKAWA S. Root-to-shoot Cd translocation via the xylem is the major process determining shoot and grain cadmium accumulation in rice. J Exp Bot, 60 (9), 2677, 2009.

5. DAGHAN H., ARSLAN M., UYGUR V., KOLELI N., EREN A. The cadmium phytoextraction efficiency of ScMTII gene bearing transgenic tobacco plant. Biotechnol Biotec Eq, 24 (3), 1974, 2010.

6. GILL S.S., HASANUZZAMAN M., NAHAR K., MACOVEI A., TUTEJA N. Importance of nitric oxide in 
cadmium stress tolerance in crop plants. Plant Physiol Bioch, 63, 254, 2013.

7. GALAL T.M., SHEHATA H.S. Impact of nutrients and heavy metals capture by weeds on the growthand production of rice (Oryza sativa L.) irrigated with different water sources. Ecoll Indic, 54, 108, 2015.

8. DAS K., MANDAL C., GHOSH N., BANERJEE S., DEY N., ADAK M.K. Effects of exogenous spermidine on cell wall composition and carbohydrate metabolism of Marsilea plants under cadmium stress. J Plant Physiol Pathol, 2, 3, 2014.

9. LIU W.T., ZHOU Q.X., AN J, SUN Y.B., LIU R. Variations in cadmium accumulation among Chinese cabbage cultivars and screening for Cd-safe cultivars. J Hazard Mater, 173, 737, 2010.

10. BURZYNSKI M., KLOBUS G. Changes of photosynthetic parameters in cucumber leaves under $\mathrm{Cu}, \mathrm{Cd}$, and $\mathrm{Pb}$ stress. Photosynthetica, 42, 505, 2004.

11. TRAN T.A., POPOVA L.P. Functions and toxicity of cadmium in plants: recent advances and future prospects. Turk J Bot, 37, 1, 2013.

12. GUPTA D.K., PENA L.B., ROMERO-PUERTAS M.C., HERNANDEZ A., INOUHE M., SANDALIO L.M. NADPH oxidases differentially regulate ROS metabolism and nutrient uptake under cadmium toxicity. Plant Cell Environ, DOI: 10.1111/pce.12711, 2016.

13. TANG Y.T., QIU R.L., ZENG X.W., YING R.R., YU F.M., ZHOU X.Y. Lead, zinc, cadmium hyperaccumulation and growth stimulation in Arabis paniculata Franch. Environ Exp Bot, 66, 126, 2009.

14. ARDUINI I., MASONI A., MARIOTTI M., PAMPANA S., ERCOLI L. Cadmium uptake and translocation in durum wheat varieties differing in grain-Cd accumulation. Plant Soil Environ, 60, 43, 2014.

15. WILSON M., NORSWORTHY J., SCOTT R., GBUR E. Program approaches to control herbicide-resistant barnyard grass (Echinochloa crus-galli) in Midsouthern United States rice. Weed Technol, 28 (1), 39, 2014.

16. BAJWA A.A., JABRAN K., SHAHID M., ALI H.H., CHAUHAN B.S., EHSANULLAH. Eco-biology and management of Echinochloa crus-galli. Crop Prot, 75, 151, 2015.

17. ABE T., FUKAMI M., ICHIZEN N., OGASAWARA M. Susceptibility of weed species to cadmium evaluated in a sand culture. Weed Biol Manag, 6, 107, 2006.

18. SULTANA R., KOBAYASHI K., KIM K. Comparison of arsenic uptake ability of barnyard grass and rice species for arsenic phytoremediation. Environ Monit Assess, 187, 4101, 2015.

19. LICHTENTHALER H.K., WELLBURN A.R. Determinations of total carotenoids and chlorophylls a and $\mathrm{b}$ of leaf extracts in different solvents. Biochem Soc T, 11 (5), 591, 1983

20. MISHRA S., SRIVASTAVA S., TRIPATHI R.D., GOVINDARAJAN R., KURIAKOSE S.V., PRASAD M.N.V. Phytochelatin synthesis and response of antioxidants during cadmium stress in Bacopa monnieri L. Plant Physiol Bioch, 44, 25, 2006.

21. ABEDI T., PAKNIYAT H. Antioxidant enzyme changes in response to drought stress in ten cultivars of oilseed rape (Brassica napus L.). Czech J Genet Plant, 46 (1), 27, 2010.

22. CLEMENS S., PALMGREN M.G., KRAMER U. A long way ahead: understanding and engineering plant metal accumulation. Trends Plant Sci, 7, 309, 2002.

23. ZHAO F.J., HAMONJ R.E., LOMBI E., MCLAUGHLIN M.J., MCGRATH S.P. Characteristics of cadmium uptake in two contrasting ecotypes of the hyperaccumulator Thlaspi caerulescens. J Exp Bot, 53, 535, 2002.

24. ARDUINI I., MASONI A., MARIOTTI M., PAMPANA S., ERCOLI L. Cadmium uptake and translocation in durum wheat varieties differing in grain-Cd accumulation. Plant Soil Environ, 60, 43, 2014.

25. HE S.Y., HE Z.L., YANG X.E., STOFFELLA P.J., BALIGAR V.C. Soil biogeochemistry, plant physiology, and phytoremediation of cadmium-contaminated soils. Adv Agron, 134, 135, 2015.

26. HAWRYLAK-NOWAK B., DRESLER S., MATRASZEK R. Exogenous malic and acetic acids reduce cadmium phytotoxicity and enhance cadmium accumulation in roots of sunflower plants. Plant Physiol Bioch, 94, 225, 2015.

27. GILL S.S., KHAN N.A., TUTEJA N. Cadmium at high dose perturbs growth, photosynthesis and nitrogen metabolism while at low dose it up regulates sulfur assimilation and antioxidant machinery in garden cress (Lepidium sativum L.). Plant Sci, 182, 112, 2012.

28. ULLAH H. A., JAVED F., WAHID A., SADIA B. Alleviating effect of exogenous application of ascorbic acid on growth and mineral nutrients in cadmium stressed barley (Hordeum vulgare) Seedlings. Int J Agric Biol, DOI: 10.17957/ IJAB/15.0064, 2016.

29. CHEN Y.X., LIN Q., LUO Y.M., HE Y.F., ZHEN S.J., YU Y.L., TIAN G.M., WONG M.H. The role of citric acid on the phytoremediation of heavy metal contaminated soil. Chemosphere, 50, 807, 2003.

30. LOPEZ-MILLAN A.F., SAGARDOY R., SOLANAS M., ABADIA A., ABADIA J. Cadmium toxicity in tomato (Lycopersicon esculentum) plants grown in hydroponics. Environ Exp Bot, 65, 376, 2009.

31. SCALET M., FEDERICE R., GUIDO M.C., MANES F. Peroxidase activity and polyamine changes in response to ozone and simulated acid rain in Aleppo pine needles. Environ Exp Bot, 35, 417, 1995.

32. WU Q., SU N.N., CAI J.T., SHEN Z.G., CUI J. Hydrogenrich water enhances cadmium tolerance in Chinese cabbage by reducing cadmium uptake and increasing antioxidant capacities. J Plant Physiol, 175, 174, 2015.

33. MISHRA S., SRIVASTAVA S., TRIPATHI R.D., GOVINDARAJAN R., KURIAKOSE S.V., PRASAD M.N.V. Phytochelatin synthesis and response of antioxidants during cadmium stress in Bacopa monnieri L. Plant Physiol Bioch, 44, 25-, 2006. 